\title{
Heat Shock Proteins: Protection and Potential Biomarkers for Ischemic Injury of Cardiomyocytes After Surgery
}

Valfredo de Almeida Santos-Junior'1, MSc; Pablo Christiano Barboza Lollo², MSc, PhD; Marcos Antonio Cantero², MD, PhD; Carolina Soares Moura ${ }^{1}$, MSc, PhD; Jaime Amaya-Farfan'1, MSc, PhD; Priscila Neder Morato' , MSc, PhD

\begin{abstract}
The heat shock proteins are endogenous proteins with the ability to act as molecular chaperones. Methods that provide cell protection by way of some damage can positively influence the results of surgery. The present review summarizes current knowledge concerning the cardioprotective role of the heat shock proteins as
\end{abstract}

occurs in heart damage, including relevant information about the stresses that regulate the expression of these proteins and their potential role as biomarkers of heart disease.

Keywords: Heat-shock response. Cytoprotection. Biomarkers. Myocardium. Infarction.

\section{Abbreviations, acronyms \& symbols \\ GGC = Geranylgeranylacetone \\ HSPs = Heat shock proteins}

\section{INTRODUCTION}

Heat shock proteins (HSPs) are a family of endogenous proteins responsible for a variety of stresses. The are classified according to their molecular weights in families, e.g. HSP27, HSP70, etc. ${ }^{[1]}$. They have the ability to act as 'molecular chaperones', since they stabilize macromolecules, guide protein folding, perform the refolding and remove irreversibly denatured proteins in the cell[2-4].

The HSPs can be overexpressed in various stress situations, such as hyperthermia ${ }^{[5,6]}$, hemodynamic stress caused by heart diseases ${ }^{[7]}$, physical exercise ${ }^{[8]}$, the administration of some substances as geranylgeranylacetone ${ }^{[9]}$ and glutamine ${ }^{[10]}$, among others.
Heart surgery improves the survival and clinical prognosis of various diseases, but can induce an ischemic/reperfusion condition that damages the cardiac tissue. Methods that induce heart protection by ischemic damage can positively influence the result of surgery. Some HSPs have been the target of studies because they increase the resistance of myocardium cells against ischemia ${ }^{[11-14]}$. Other studies verified the relationship between HSPs and the development of heart disease ${ }^{[15-17]}$. Since failures in the detection of heart diseases can worsen the odds, more sensitive methods could significantly increase patient survival.

The expression of HSPs in the heart has been the focus of several studies, but some questions still need clarification, such as: do all HSPs have a protective effect? Would increases in HSPs serve as new biomarkers for the diagnosis/prognosis of cardiovascular diseases? Would the increase offer advantages/ improvements in the clinical outcome of cardiovascular diseases? As from these doubts, the objective of the present study was to systematically analyze the published studies concerning the expression of HSPs in the heart.
${ }^{1}$ Faculdade de Engenharia de Alimentos (FEA) da Universidade Estadual de Campinas (Unicamp), Campinas, SP, Brazil.

${ }^{2}$ Faculdade de Ciências da Saúde (FCS) da Universidade Federal da Grande Dourados (UFGD), Dourados, MS, Brazil.

This study was carried out at Faculdade Faculdade de Engenharia de Alimentos (FEA) da Universidade Estadual de Campinas (Unicamp), Campinas, SP, Brazil.
No conflict of interest.

Correspondence Address:

Valfredo de Almeida Santos-Junior

Universidade Estadual de Campinas

Rua Monteiro Lobato, 80, FEA/Unicamp - Campinas, SP, Brazil - Zip code: 13083-862 E-mail: juniorfex@gmail.com 


\section{METHODS}

The literature survey was carried out based on the PubMed data using the descriptors"Heat shock protein"and "heart"as components of the search field title. The objective was to select articles that researched the expression of HSPs specifically in the heart. We found 90 articles, among which those that included the objectives of the search were selected, excluding articles in languages other than English, and texts that were not complete articles or made conclusions about other substances/means or that did not report directly on the problems/cardiac tissues (Figure 1).

\section{RESULTS AND DISCUSSION}

\section{HSPs and Heart Protection}

HSP70 and some other small heat shock proteins (SHSPs) were found to provide heart protection. Of the 69 articles included in this study, 26 dealt with the effect of the HSPs in heart protection and 25 showed that the presence of these proteins was associated with the protective effect in cardiac tissue ${ }^{[5,9,11-14,18-36]}$.

Part of the myocardial protection granted, according to the authors, was due to the effect of HSP70 in response to ischemic damage. Yamashita et al. ${ }^{[18]}$ and Kukreja et al. ${ }^{[19]}$ induced the superexpression of HSP70, thus obtaining a significant reduction in the infarcted area. Qian et al. ${ }^{[20]}$, Okubo et al. ${ }^{[12]}$, Vittorini et al. ${ }^{[14]}$, Zhao et al. ${ }^{[32]}$ and Li et al. ${ }^{[34]}$ reported similar results. Additionally, Yamashita et al.[18] showed that HSP70 content correlated with the time course of cardioprotection. Furthermore, an increase in HSP70 expression can prevent lipopolysaccharide-induced dysfunction ${ }^{[21]}$. Only Xi et al. ${ }^{[37]}$ did not observe diferences in infarct size between the HSP70 and control groups.

In addition to the decrease in the infarcted area, an increase in the expression of HSP70 offers an improvement in the recovery of post-ischemia/reperfusion injury $[9,11,22,24,28]$. Nomura
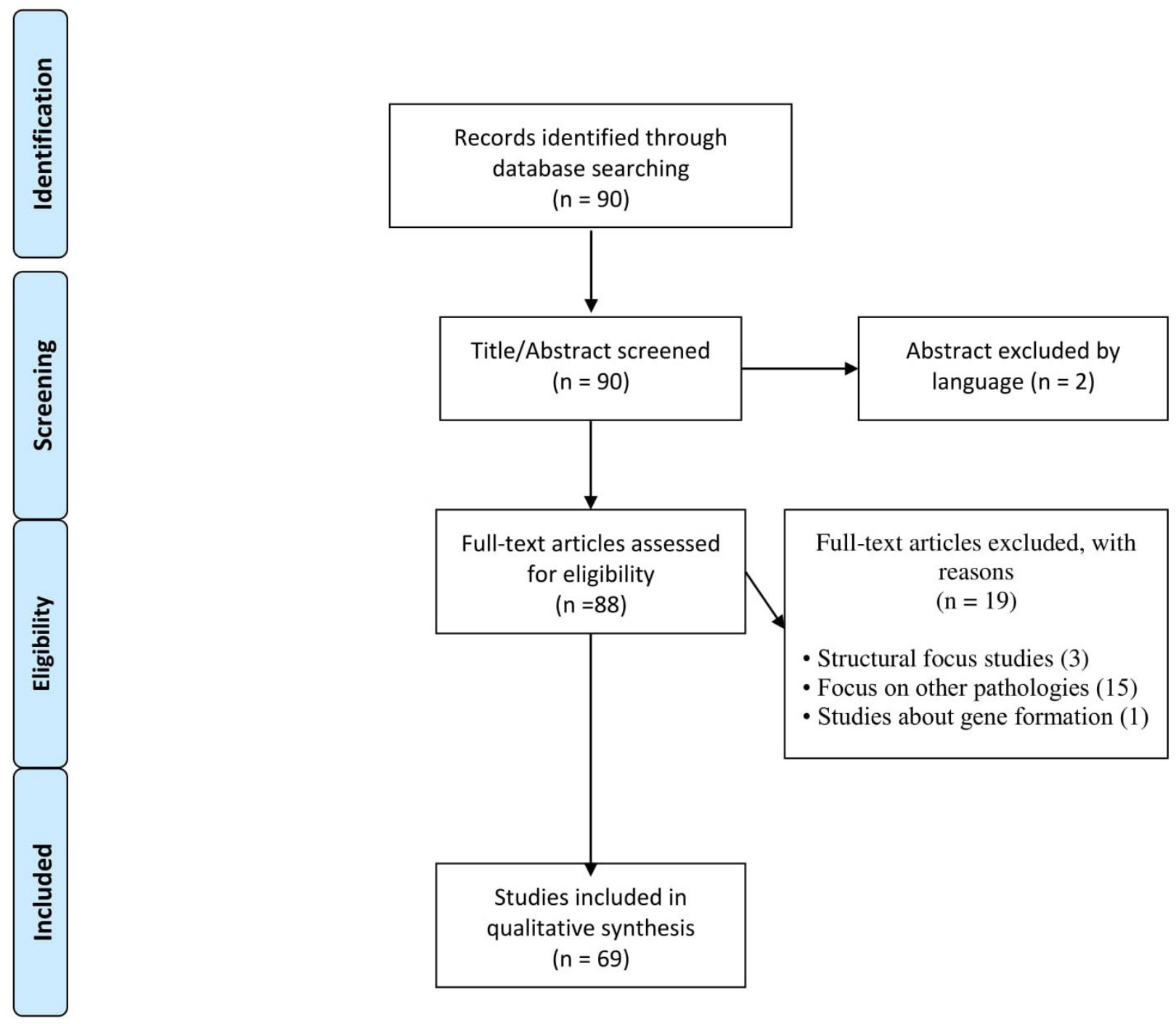

Fig. 1 - Flow diagram showing the inclusion and exclusion criteria of the articles. 
et al..[22] verified that upregulation of HSP70 before cardioplegic ischemia improved the recovery of systolic and coronary endothelian function. Ooie et al. ${ }^{[2]}$ demonstrated that an increase in HSP70 expression induced by geranylgeranylacetone (GGC) significantly improved post-ischemia heart recovery and decreased the cardiac injury markers.

Tanonaka et al..$^{[5]}$ demonstrated that an increase in HSP70 was inversely correlated with worsening of cardiac parameters. However, an infarcted heart appears to have a lower production capacity of HSP70, which could be intimately related to its functional deterioration and ability to tolerate further damage ${ }^{[5]}$. An increase of HSP70 expression is also correlated with a decrease in heart apoptosis ${ }^{[2,30]}$. Both authors explored the expression of this protein as related to changes in endogenous hormones, but the role of these hormones on the expression of HSP70 is still unclear.

In addition, sHSPs also promote heart protection [13,23,25,27,29,31,33,35]. Kim et al.[23], Efthymiou et al. ${ }^{[25]}$ and Kwon et al. ${ }^{[13]}$ found that HSP27 offered a protective effect in cases of infarction. Groups that overexpressed HSP27 presented significant reductions in the infarcted areas and reductions in cell apoptosis in cardiac tissue. Zhu and Wang ${ }^{[29]}$ observed these same characteristics with increased expression of HSP2O.

Chen et al. ${ }^{[27]}$ reveals that type-1 diabetic hearts are resistant to ischemic injury by upregulation of phosphorylated HSP27 and the low expression of HSP27 was associated with atrial fibrillation in patients with rheumatic heart disease ${ }^{[36]}$. An increase in the expression of HSP27 also provided an increase in the efficiency of stem cell therapy in the myocardial recovery, decreasing cell apoptosis and improving heart recovery during therapy ${ }^{[35]}$.

Jiang et al[.[3] obtained similar results with increased expression of HSP32, which promoted heart protection following ischemia/reperfusion. An increase in the expression of HSP25 improved survival in patients with cardiomyopathy and increased heart resistance against toxicity ${ }^{[31]}$.

\section{Induction of the Expression of HSPs}

Hyperthermia is one of the main and best known inducers of HSP expression, and of the articles included in this systematic review, twelve used this method to increase the protein expression $[5-7,18-20,22,26,30,37-39]$. However, depending on tissue type

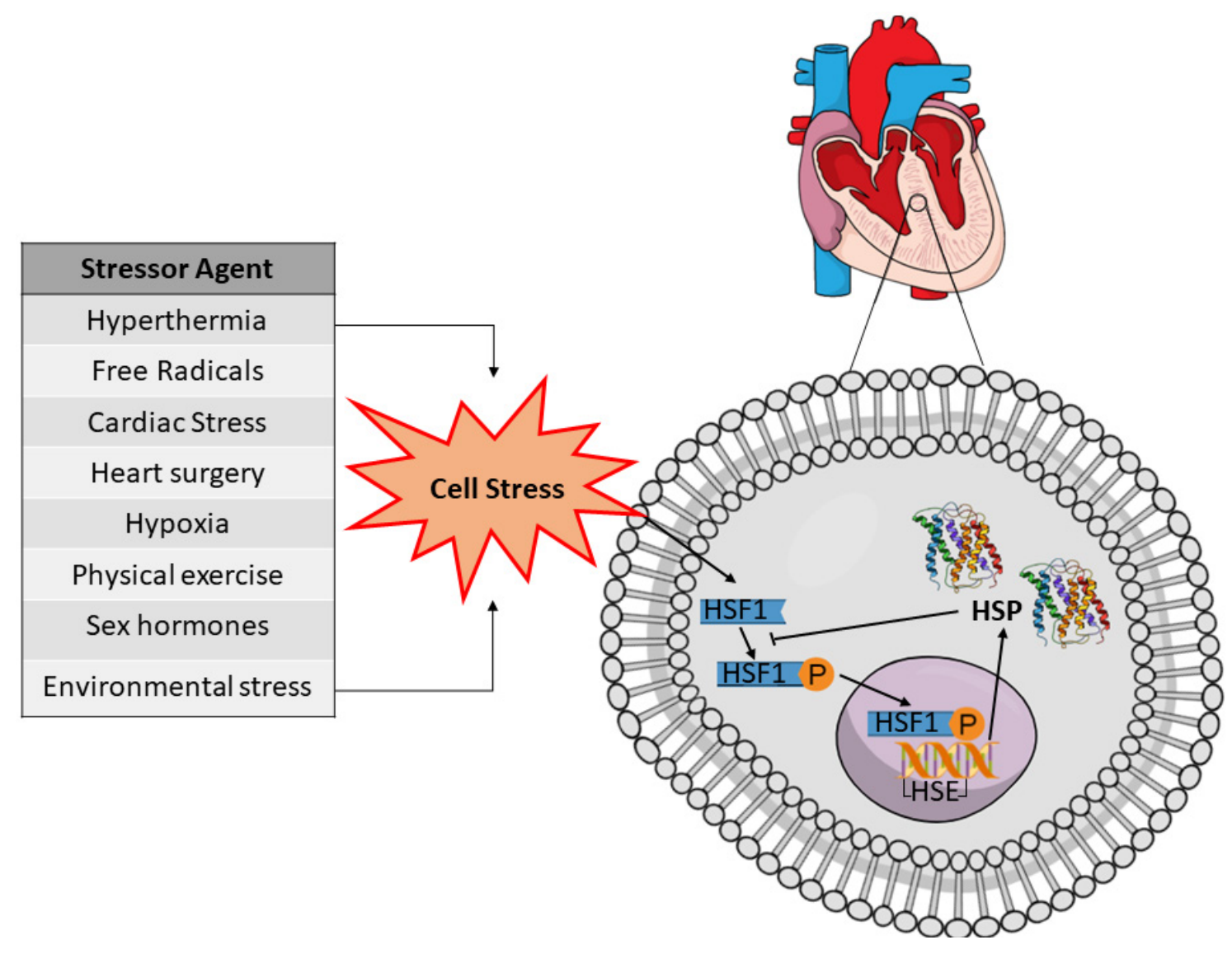

Fig. 2 - General scheme of some of the physiological signals that activate the inducible form of the heat shock protein (HSP) in the cardiac cell. Physiological stress is required to enable access to heat shock factor-1 (HSF-1) complex present in the cytosol, allowing its phosphorylation (P) by protein kinases to their active form. These HSF-1 phosphorylated complexes enter the nucleus and bind to heat shock elements (HSE) in the promoter region of the HSP-especific gene. Transcriptional and translational processes increase HSP expression in the cellular cytosol. 
and HSP, increased expression can be influenced by several other types of stress, as shown in the general scheme of Figure 2.

\section{HSP70}

Some substances also influence the regulation of HSP70: circulating hormones like phenyleprine and vasopressin${ }^{[38]}$, free radicall ${ }^{[40]}$, treatment with geranylgeranylcetone ${ }^{[9,24]}$, liposomal protein delivery of $\mathrm{HSP}^{2} \mathrm{O}^{[21]}$, intravenous injection of anandamide ${ }^{[34]}$, chronic administration of Terminalia arjuna ${ }^{[28]}$, injection of HSP70 adenovirus ${ }^{[12]}$, probiotic-derived proteins ${ }^{[32]}$ and parenteral administration of glutamine ${ }^{[10]}$. All these were shown to be effective in increasing the expression of this protein.

Pathologies induce systematic stress that could superexpress HSP70 in the heart. Wei et al. ${ }^{[15]}$ verified that the protein expression of HSP70 is frequently increased in hearts showing failure due to arrhythmogenic cardiomyopathy, dilated cardiomyopathy and ischemia. Ferrari et al. ${ }^{[41]}$ verified that congestive heart failure increases HSP72 expression more pronounced in right than left ventricles, whereas hibernation increases expression in both. The initial stages of heart failure ${ }^{[42,43]}$, elevation of aortic pressure ${ }^{[44]}$ and diabetes mellitus ${ }^{[10]}$ increase the expression of HSP70 in the heart tissue as a form of protection.

However, as failure proceeds, repression of the nuclear portion of HSF-1 (heat shock factor 1) ensues thus inhibiting the expression of HSP70 in the more serious stages of the disease ${ }^{[5,7,73-46]}$. Two studies verified the involvement of diabetes mellitus in HSP70 expression ${ }^{[1,227]}$. Ugurlucan et al. ${ }^{[10]}$ demonstrated an increase of HSP70 in diabetic hearts, while Chen et al. ${ }^{[27]}$ observed no differences between the control and diabetic groups. Further research is essential to clarify the effects of diabetes mellitus on the expression of HSP70 in the heart.

Steroid hormones alter the expression of HSP70 differently in men and women. Treatment with 17-B-estradiol or progesterone can activate HSF-1 and consequently increase the HSP7O expression, but not of the other HSPs[4]. Shinohara et al.[26] found that male hearts are more sensitive to the induction of HSP70 and the author explained that this finding was due to the inhibitory effect of estrogen on the HSP70 expression. However, Kohno et al. ${ }^{[30]}$ showed that testosterone also had an inhibitory effect on the expression of HSP70, this inhibition being mediated by testosterone receptors in the heart tissue. Further research is required in this field, since the analysis of the results of these two studies seems to indicate that both sex hormones have an inhibitory effect, although estrogen may be a more potent inhibitor than testosterone, unless other factors are involved in the regulation process.

The stress produced by the heart surgery itself has been shown to induce an increase in HSP70 expression. Schmitt et al. ${ }^{[48]}$ reported a superexpression of HSP70 after stress caused by cardioplegic arrest, which was proportional to the duration of the cardioplegia. The increase became more pronounced after two hours, leading to the conclusion that the synthesis peaks at about two hours in human hearts. There were no significant changes in the HSPs of other molecular weights.

Similar results were found by Vittorini et al. ${ }^{[14]}$ and Dybdahl et al.[49], who observed that cardioplegia positively regulated the expression of HSP70. Ischemia/reperfusion preconditioning upregulates the HSP70 expression ${ }^{[20,50]}$. Hypothermic cardioplegia showed increase the HSP70 expression even more than normothermic controls, but only one study tested this hypothesis and this topic needs more research ${ }^{[51]}$.

Other types of cardiac stress have been shown to be efficient in increasing HSP70 expression, such as height-induced hypoxia, remaining high for up to two weeks ${ }^{[1]}$ or pulmonar artery banding ${ }^{[52]}$, a single stretch and fiber shortening ${ }^{[53]}$, physical exercise $^{[8]}$ and stress caused by environmental changes ${ }^{[54]}$.

\section{HSP60}

The increase in HSP60 expression due to hyperthermia is tissue-specific. Yan et al[.55], verified the behavior of HSP60 under acute heat conditions and showed that the expression was tissue-specific and that the increase was related to the extent of damage to the tissue. In the heart, HSP60 started increasing after one hour of induction and reached a peak after five hours.

On analyzing the protein expression induced by the development of heart failure, Tanonaka et al. ${ }^{[43]}$ showed that HSP60 levels only increased in the eighth week, when functional changes occurred that defined the presence of the pathology. Hoppichler et al.[56] found an increase in HSP60 antibodies in chronic heart disease. Wang et al. ${ }^{[46]}$ demonstrated that the increase in HSP60 during heart failure could be mediated by the increase in circulating NFkB. In the reviewed articles, only three dealt with forms of inducing HSP60 expression.

\section{Small Heat Shock Protein (HSP20, 25 and 27)}

Stress induced by some diseases affects the expression of HSP27 and some other HSPs. Tanonaka et al. ${ }^{[43]}$ found that at the onset of heart failure there was an increase in HSP27. Corroborating the finding above, Dohke et al. ${ }^{[5]}$ observed an increase in phosphorylation of HSP2O and HSP27. Ischemic preconditioning also increases HSP27 expression ${ }^{[23]}$. Hu et al. ${ }^{[58]}$ demonstrated a reduction in the expressions of HSP27 and HSP32 in the heart following intracerebral hemorrhage, but treatment with deferoxamine reversed the reduction in HSP32, although making the reduction in HSP27 even more pronounced.

Raju et al. ${ }^{[45]}$ observed that congestive heart failure increases HSP32 without changing HSP70 expression, showing that HSPS behave in distinct manners with each other. The regulation of some sHSP may be correlated with endogenous proteins. As published by Jiang et al. ${ }^{[33]}$, nucleolin interacts with the mRNA of HSP32 increasing its stability and consequently its expression.

McGinley et al. ${ }^{[35]}$ noted that it was possible to increase the expression of HSP27 by treating with lentivirus vectors, an effect similar to that demonstrated by Kwon et al. ${ }^{[13]}$, which induced an increase in HSP27 using a protein delivery system by recombinant HSP27 linked to a protein transduction domain. The adenoviruses HSP2O and HSP22 were also efficient in increasing the expression of these proteins in cardiomyocytes ${ }^{[22]}$. Pretreatment with HSP25 enriched plasma also induced an increase in the expression of extracellular HSP25, according to a study published by Krishnamurthy et al. ${ }^{[31]}$.

Systemic stress positively regulate the expression of HSPs. Physical exercise increased the expression of $\mathrm{HSP} 27^{[8]}$, and Boluyt 
et al. ${ }^{[59]}$ showed that only chronic physical training caused an increase in HSP2O expression, which persisted for at least 72 hours of detraining. Stresses such as drug abstinence induced an increase in HSP, as verified by the work of Almela et al. ${ }^{[60]}$, where morphine-dependent rats showed an increase in HSP27 expression upon receiving saline instead of morphine.

\section{HSPs as Potential Biomarkers for Heart Disease}

Due to their characteristic response to diverse stresses, including heart disease, the power of HSPs as diagnostic and prognostic markers for heart disease has been investigated. Of the papers included in this study, 21 of them verified this relationship ${ }^{[5,15,17,42,45,49,56,57,61-72] \text {. }}$

Of these studies, nine investigated the relationship of HSP60 expression and its potential to detect heart disease, and seven of them showed that HSP60 had the potential to be a diagnostic or prognostic marker of heart disease. Veres et al. ${ }^{[64]}$ and Zhang et al. ${ }^{[70]}$ verified that high levels of HSP60 could increase the risk of heart disease and could be considered as a new familial risk factor for these diseases.

Elevated HSP60 concentrations were positively associated with the severity of coronary arterial disease in a dosedependent way ${ }^{[70,71]}$ and with ischemic heart disease ${ }^{[68]}$, and also showed a correlation with heart failure and other adverse cardiac events and antibodies levels in sera can be correlated with worse prognosis ${ }^{[16,61,69]}$. Only Hoppichler et al. ${ }^{[56]}$ and Rothenbacher et al. ${ }^{[63]}$ reported that high levels of HSP60 did not correlate with the risk factor for heart disease.

Of the ten studies that verified the role of HSP70 as a possible biomarker for heart disease, nine came to a positive conclusion. The pioneering work of Comini et al. ${ }^{[42]}$ was confirmed by GenthZotz et al. ${ }^{[65]}$ and Gombos et al. ${ }^{[67]}$, who found that the levels of this protein were significantly higher in the groups with heart failure and that this expression was related to the severity of the disease. In agreement with those reports, Wei et al. ${ }^{[15]}$ also observed that an increase in the expression of HSP70 was common in heart failure.

Comini et al. ${ }^{[42]}$ showed that congestive heart failure, but not compensatory hypertrophy, increases HSP70 expression in heart. Only Raju et al. ${ }^{[45]}$ found no changes in HSP70 expression in the congestive heart failure model. Patients with myorcardial infarction also show higher levels of HSP70 than control subjects ${ }^{[6]}$. Another fact that supports its use as a diagnostic/prognostic biomarker of heart disease is the correlation that has been reported between HSP70 and the traditional injury markers such as AST, ALT, YGT and bilirubin in patients with heart failure ${ }^{[5,67]}$.

In assessing the relationship between HSP70 and progression of heart failure, Li et al. ${ }^{[17]}$ verified a significant increase with the progression of disease stages, showing their potential for detection, mainly in old myocardial infarction or in those whith structural heart disease. Baba et al. ${ }^{[62]}$ concluded that worse parameters correlate with increased HSP70 and that this increase was inversely correlated with rejection in the case of heart transplantation. Dybdahl et al. ${ }^{[49]}$ concluded that measurement of increased levels of HSP70 in post-cardiac surgery tissue and ischemia could offer an advantage in the diagnosis and prognosis of such cases.
Increased SHSPs are also correlated with heart failure, and HSP27 can be used as a marker for this purpose. It was shown that HSP20, HSP27 and HSP32 were involved in congestive heart failure due to significant increases in the phosphorylated forms that appear in this disease ${ }^{[45,57]}$. An increase in HSP27 was correlated with the progression of heart failure in animals $s^{[17]}$, and in humans HSP27 was significantly higher in patients with valvular heart disease ${ }^{[72]}$, suggesting its use as a marker for disease.

\section{Influence of HSP on Heart Health}

HSPs work as a cellular defense mechanism, acting as a complementary antioxidant system; the oxidative stress inducing an increase in the expression of one or several HSPs, and this increase in turn promotes protection ${ }^{[8]}$ through repairing. The accumulation of reactive oxygen species throughout a lifetime, however, can affect the efficiency and homeostasis of the cellular system.

Ageing negatively affects HSP70 expression in the heart, leaving the heart more susceptible to oxidative damage, but Rinaldi et al. ${ }^{[8]}$ showed that physical exercise increased the expression of HSP70 and HSP27 in the heart. In fact, the expression of these proteins inhibits apoptosis and protects the integrity of actin and cardiac microtubule cytoskeleton ${ }^{[46]}$, thus explaining in part the beneficial effect of exercise on the heart of the elderly.

HSP70 is an endogenous activator of the innate immune system ${ }^{[49,66]}$. The circulating levels of HSP70 not only act as molecular chaperones but are also correlated with the decrease of inflammatory cytokines. An in vitro study proved the release of inflammatory cytokines mediated by HSP70, TLR4 receptor agonists ${ }^{[66]}$. Dybdahl et al. ${ }^{[49]}$ found that HSP70 did, in fact, induce an increase in IL-6 and TNF in a dose-dependent manner via TLR4/CD14, thus demonstrating the involvement of HSP70 in the inflammatory response.

Besides guiding the initial protein folding, some small heat shock proteins help in heart protection and function. Qiu et al. ${ }^{[73]}$ demonstrated that HSP22 depletion did not affect heart function under basal conditions, but following cardiac overload, its absence promoted eccentric hypertrophy and dilation of the heart, accelerated the transition to heart failure, and interfered in the activation of the cellular protection system.

Additionally, an increase in HSP25 expression can prevent apoptosis signaling, antagonizing the activation of TLR2 after systemic stress, such as in the case of toxic treatments or the accumulation of denatured proteins ${ }^{[31]}$. HSP20 positively interferes in the contractile capacity of the heart; the overexpression of HSP2O is a beneficial factor for heart tissue, since it acts in the cellular protection against several types of stress and simultaneously improves the contractile function ${ }^{[59]}$.

Table 1 presents a summary of the evidence.

\section{CONCLUSION}

In summary, the literature provides consistent evidence that HSP20, HSP25, HSP27, HSP32 and HSP70 promote a protective effect following heart damage. Overexpression of these proteins 
in cardiac tissue increases protection as a natural result of ischemic damage, decreases infarcted area and myocardial apoptosis, and aids in heart recovery.

The increase in expression of these proteins can occur through some systemic stresses, such as hyper-and hypothermia, hypoxia, physical exercise and cardioplegia, as well as some substances and treatments, or the stress produced by heart disease. The sum of these findings could be useful under conditions in which it is necessary to induce ischemic damage, as in the case of surgery with cardiopulmonary bypass or other surgical procedures that include the temporary cutoff of supplies to the heart, in addition to improving cardiovascular endurance through heart disease. However, studies and procedures in human subjects still need to be more widely studied.

Although limited, knowledge on the role of HSPs as possible biomarkers has shown that HSP20, HSP27, HSP60 and HSP70 correlate well with heart disease, disease severity and resulting adverse events, the use of these proteins in the myocardium or in the blood is currently under evaluation as predictive markers in pre- and post-surgery. Little or no reference has been found in the literature, however, about the possibility of manipulating the production of these repair proteins. However, a likely practical application for the use of HSPs could be available if we could either enhance the overexpression by specific diet or avoid the use of practices or therapeutic procedures that could jeopardize the expression of HSPs and their benefits. While our understanding of these major HSPs in heart disease is incomplete, there is a clear potential role for the therapeutic modulation of HSPs in the practical clinical context. In the absence of such data, further studies would be required to better explore this natural repair system, perhaps even as a tool to evaluate the success of the therapy.

Table 1. Summary of evidence.

\begin{tabular}{|c|c|c|}
\hline Author & Objective & Results/Conclusion \\
\hline Almela et al. ${ }^{[60]}$ & $\begin{array}{l}\text { To investigate the HSP27 expression during morphine } \\
\text { dependence and withdrawal }\end{array}$ & Morphine withdrawal $\uparrow$ HSP27 in heart \\
\hline Baba et al. ${ }^{[62]}$ & $\begin{array}{c}\text { To determine the correlation between hemodynamic } \\
\text { parameters and HSP70 in the early period after heart } \\
\text { transplantation }\end{array}$ & $\begin{array}{c}\text { Worsening of the parameters is correlated with } \uparrow \text { HSP70 } \\
\text { / Patients who died and in case of transplant rejection } \\
\text { was observed more } \uparrow \text { HSP / } \\
\uparrow \text { HSP70 was inversely correlated with rejection }\end{array}$ \\
\hline Boluyt et al. ${ }^{[59]}$ & $\begin{array}{c}\text { To determine the protein changes in the heart after } \\
\text { physical training }\end{array}$ & $\begin{array}{c}\text { Chronic physical training } \uparrow \text { HSP20 / } \uparrow \text { HSP20 can stay up } \\
\text { to } 72 \mathrm{~h} \text { after physical training }\end{array}$ \\
\hline Bonanad et al..16] & $\begin{array}{l}\text { To evaluate the correlation between HSP60 and the risk } \\
\text { of death/recurrence of acute HF }\end{array}$ & $\uparrow$ HSP60 related to risk of death/recurrence \\
\hline Chen et al. ${ }^{[27]}$ & $\begin{array}{l}\text { To investigate the response of HSPs and tolerance of } \\
\text { type } 1 \text { diabetic hearts to ischemia/reperfusion injury }\end{array}$ & $\begin{array}{l}\uparrow \text { HSP27 phosphorylated and } \uparrow \text { injury tolerance in } \\
\text { diabetic hearts } / \leftrightarrow \text { HSP70 in diabetic hearts }\end{array}$ \\
\hline Comini et al. ${ }^{[43]}$ & $\begin{array}{l}\text { To investigate the HSP70 expression in lungs, liver, } \\
\text { cardiac and skeletal muscle in congestive heart failure }\end{array}$ & $\begin{array}{c}\text { CHF, but not compensatory hypertrophy } \uparrow \text { HSP70 in } \\
\text { heart }\end{array}$ \\
\hline Dohke et al. ${ }^{[57]}$ & To evaluate the change of protein expression in HF & $\uparrow$ HSP27 and $\uparrow$ HSP2O in hearts with HF \\
\hline Dybdahl et al..49] & To explore the release of HSP70 after CABG & $\begin{array}{l}\uparrow \text { HSP70 release after } \mathrm{CABG} / \uparrow \mathrm{HSP} 70 \text { related to } \uparrow \mathrm{IL}-6 \\
\text { and } \uparrow \mathrm{TNF}\end{array}$ \\
\hline Efthymiou et al. ${ }^{[25]}$ & $\begin{array}{c}\text { To investigate the heart response overexpressing HSP27 } \\
\text { to ischemia/reperfusion injury }\end{array}$ & $\begin{array}{c}\uparrow \text { HSP27 } \downarrow \text { the infarct size } / \uparrow \text { HSP27 protected the heart } \\
\text { from ischemia/reperfusion injury }\end{array}$ \\
\hline Ferrari et al. ${ }^{[42]}$ & $\begin{array}{c}\text { To compare myocardial hibernation and congestive } \\
\text { heart failure in HSP72 expression }\end{array}$ & $\begin{array}{c}\text { Myocardial hibernation } \uparrow \text { HSP72 in right and left } \\
\text { ventricles / Congestive heart failure } \uparrow \text { HSP72 more } \\
\text { marked in the right than in the left ventricle }\end{array}$ \\
\hline Gauthaman et al. ${ }^{[28]}$ & $\begin{array}{l}\text { To investigate the effect of Terminalia arjuna (TA) on HSP } \\
\text { expression and its influence on ischemic damage }\end{array}$ & $\begin{array}{l}\text { Terminalia arjuna treatment } \uparrow \text { HSP72 / Treatment } \uparrow \text { the } \\
\text { recovery of cardiac function after ischemia/reperfusion }\end{array}$ \\
\hline Genth-Zotz et al..65] & $\begin{array}{l}\text { To investigate the circulating HSP70 levels in patients } \\
\qquad \text { with CHF }\end{array}$ & $\begin{array}{c}\uparrow \text { HSP70 in CHF patients / } \uparrow \text { HSP70 related to disease } \\
\text { severity }\end{array}$ \\
\hline Gombos et al..67] & $\begin{array}{l}\text { To investigate the clinical and biological correlation of } \\
\qquad \text { HSP70 in HF }\end{array}$ & $\begin{array}{c}\uparrow \text { HSP70 levels were associated with disease severity in } \\
\text { HF patients / } \uparrow \text { HSP70 correlated with markers of cardiac } \\
\text { function and liver injury }\end{array}$ \\
\hline
\end{tabular}




\begin{tabular}{|c|c|c|}
\hline Gray et al. ${ }^{[51]}$ & $\begin{array}{l}\text { Investigate the effect of hypothermic cardioplegic arrest } \\
\text { in the expression of HSP70 }\end{array}$ & $\begin{array}{l}\text { The hypothermic cardioplegic } \uparrow \text { HSP70 more than } \\
\text { normothermic control }\end{array}$ \\
\hline Hoppichler et al. ${ }^{[56]}$ & $\begin{array}{c}\text { To investigate the association between HSP60 } \\
\text { antibodies with coronary heart disease and acute } \\
\text { myocardial infarction }\end{array}$ & $\begin{array}{c}\text { CHD } \downarrow \text { HSP60 / Myocardial infarction } \downarrow \text { HSP60 } \\
\text { antibodies compared to CHD }\end{array}$ \\
\hline Hu et al. ${ }^{[58]}$ & To examine the expression of HSPs in the heart after ICH & ICH $\downarrow$ HSP27 and $\downarrow$ HSP32 in the heart \\
\hline Jafarzadeh et al. ${ }^{[68]}$ & $\begin{array}{c}\text { To evaluate HSP60 in patients with ischemic heart } \\
\text { disease }\end{array}$ & $\begin{array}{l}\uparrow \text { HSP60 in the groups of patients compared to control } \\
\text { groups }\end{array}$ \\
\hline Jiang et al. ${ }^{[33]}$ & $\begin{array}{l}\text { To investigate the role of nucleolin in cardiac ischemia/ } \\
\text { reperfusion injury }\end{array}$ & Nucleolin $\uparrow$ HSP32 / $\uparrow$ HSP32 offers cardiac protection \\
\hline Katayose et al. ${ }^{[52]}$ & $\begin{array}{c}\text { To examine the expression of heme oxygenase (HSP32) } \\
\text { and HSP70 in hearts subjected to hypoxia or pulmonary } \\
\text { artery banding }\end{array}$ & $\begin{array}{c}\text { Hypoxia } \uparrow \text { HSP32 e } \leftrightarrow \text { HSP70 in right and left ventricle / } \\
\text { Pulmonary artery banding } \uparrow \text { HSP32 and } \uparrow \text { HSP70 }\end{array}$ \\
\hline Kim et al. ${ }^{[23]}$ & $\begin{array}{l}\text { To examine whether extracellular kinases are } \\
\text { upregulated by preconditioning and whether they are } \\
\text { required for cadioprotection }\end{array}$ & Preconditioning $\uparrow$ HSP27 and $\downarrow$ infarct size \\
\hline Knowlton and Sun ${ }^{[47]}$ & $\begin{array}{c}\text { To investigate the relationship between HSPs and } \\
\text { hormone receptors }\end{array}$ & 17-B-estradiol or progesterone $\uparrow$ HSF-1 and $\uparrow$ HSP70 \\
\hline Knowlton et al. ${ }^{[53]}$ & $\begin{array}{l}\text { To investigate the effect of decreased systolic } \\
\text { shortening and a single stretch on HSP70 expression }\end{array}$ & Single stretch and fiber shortening $\uparrow$ HSP70 \\
\hline Kohno et al. ${ }^{[30]}$ & $\begin{array}{l}\text { To investigate the effects of testosterone on HSP72 } \\
\text { expression and its relation to cardioprotection }\end{array}$ & $\begin{array}{c}\text { Exogenous testosterone } \downarrow \text { HSP72 after heat stress } / \uparrow \\
\text { HSP72 correlates } \downarrow \text { cardiac apoptosis and } \uparrow \text { functional } \\
\text { recovery }\end{array}$ \\
\hline $\begin{array}{l}\text { Krishanarmurthy et } \\
\text { al.[31] }\end{array}$ & $\begin{array}{l}\text { To determine the relationship between HSP25 and } \\
\text { protection against cardiotoxicity }\end{array}$ & $\uparrow$ HSP25 protected the heart from cardiotoxicity \\
\hline Kukreja et al. ${ }^{[41]}$ & $\begin{array}{l}\text { To examine the influence of free radicals on HSP70 } \\
\text { expression in the heart }\end{array}$ & Free radicals $\uparrow \mathrm{HSP} 70$ \\
\hline Kukreja et al. ${ }^{[19]}$ & $\begin{array}{c}\text { To verify the hypothesis that inhibition of protein kinase } \\
\text { C would block the cardioprotection mediated by heat } \\
\text { stress }\end{array}$ & $\begin{aligned} \text { Heat stress } \uparrow \text { HSP70 and } \downarrow \text { infarct size / PKC inhibitor } \\
$\[ \text { HSP70 } \]$\end{aligned}$ \\
\hline Kwon et al. ${ }^{[13]}$ & $\begin{array}{c}\text { To evaluate the efficacy of an intracellular delivery } \\
\text { system in the expression of HSP27 and in cardiac } \\
\text { protection }\end{array}$ & $\begin{array}{c}\text { Intracellular delivery system } \uparrow \text { HSP27 / } \uparrow \text { HSP27 } \\
\downarrow \text { apoptosis and } \downarrow \text { size of the infarcted area / } \uparrow \text { HSP27 } \\
\text { promotes heart protection against ischemia }\end{array}$ \\
\hline Latif et al. ${ }^{[61]}$ & $\begin{array}{c}\text { To quantify levels of circulating anti-HSP60 antibodies in } \\
\text { the cardiac transplant patient }\end{array}$ & $\begin{array}{c}\uparrow \text { HSP60 antibodies in sera appear to have a worse } \\
\text { prognosis }\end{array}$ \\
\hline Li et al. ${ }^{[34]}$ & $\begin{array}{l}\text { To test the effect of anandamide in HSP72 expression } \\
\text { and cardioprotection }\end{array}$ & $\begin{array}{l}\text { Anadamide } \uparrow \text { HSP70 and protect the heart against } \\
\text { ischemia/reperfusion injury }\end{array}$ \\
\hline Li et al. ${ }^{[17]}$ & To characterize the expression of circulating HSP in HF & $\begin{array}{l}\uparrow \mathrm{HSP} 27 \text { and } \uparrow \text { HSP70 in animals and } \uparrow \text { HSP70 in } \\
\text { humans with HF / } \uparrow \text { HSP70 with progression of HF }\end{array}$ \\
\hline Marunouchi et al. ${ }^{[7]}$ & To analyze the HSF-1 and HSP70 kinetics after HF & $\begin{array}{c}\uparrow \text { HSP72 and } \uparrow \text { HSF } 1 \text { in the } 2^{\text {nd }} \text { week after HF / } \\
\downarrow \text { HSP72 and } \downarrow \text { HSF } 1 \text { after heat exposure with disease } \\
\text { progression }\end{array}$ \\
\hline McGinley et al. ${ }^{[35]}$ & $\begin{array}{l}\text { To investigate the effect of exogenous HSP27 on } \\
\text { mesenchymal stem cell therapy in the heart }\end{array}$ & $\begin{array}{c}\uparrow \text { HSP27 } \uparrow \text { the survival of cell therapy in vitro and in vivo } \\
\qquad / \uparrow \text { HSP27 } \downarrow \text { apoptosis and } \uparrow \text { cardiac function }\end{array}$ \\
\hline Meldrum et al. ${ }^{[21]}$ & $\begin{array}{l}\text { To determine the effect of liposomal delivery of HSP70 } \\
\text { and the role in cardioprotection }\end{array}$ & $\begin{array}{l}\text { Intracoronary perfusion of the liposomal protein } \\
\uparrow \text { HSP70 in the myocardium / } \uparrow \text { HSP70 prevents LPS- } \\
\text { induced dysfunction }\end{array}$ \\
\hline
\end{tabular}




\begin{tabular}{|c|c|c|}
\hline Moalic et al. ${ }^{[38]}$ & $\begin{array}{l}\text { To verify the involvement of circulating hormones in } \\
\qquad \text { HSP70 expression }\end{array}$ & $\begin{array}{l}\text { Heat stress } \uparrow \text { HSP70 / Phenylephrine and vasopressin } \\
\qquad \begin{array}{l}\text { HSP70, but angiotensin II did not }\end{array}\end{array}$ \\
\hline Niizeki et al. ${ }^{[69]}$ & $\begin{array}{c}\text { To examine whether HSP } 60 \text { is correlated with the } \\
\text { severity of CHF }\end{array}$ & $\begin{array}{c}\text { 个 HSP60 in patients with CHF to the control group / } \\
\uparrow \text { HSP60 was associated with functional classification of } \\
\text { CHF and risk of adverse events }\end{array}$ \\
\hline Nomura et al.[22] & $\begin{array}{l}\text { To investigate the role of HSP70 in the recovery of } \\
\text { hypothermic cardioplegic ischemia }\end{array}$ & $\begin{array}{l}\uparrow \text { HSP70 expression in } 15 \text { min after heat stress }\left(43^{\circ}\right) \text { and } \\
\text { persisted up to } 24 \mathrm{~h} / \uparrow \text { HSP70 improved the recovery of } \\
\text { systolic and coronary endothelial function }\end{array}$ \\
\hline Okubo et al. ${ }^{[12]}$ & $\begin{array}{l}\text { To observe the effect of the overexpression of HSP70 in } \\
\text { myocardial protection }\end{array}$ & $\begin{array}{c}\uparrow \text { HSP70 } \downarrow \text { myocardial infarct size / } \uparrow \text { HSP70 } \downarrow \text { the } \\
\text { severity of ischemic injury }\end{array}$ \\
\hline Ooie et al. ${ }^{[24]}$ & $\begin{array}{l}\text { To examine the role of geranylgeranyl acetone (GGA) in } \\
\text { HSP expression in cardioprotection }\end{array}$ & $\begin{array}{c}\text { Treatment } \uparrow \text { HSP70 dose-dependent manner with peak } \\
\text { expression at } 24 \text { hours after administration / } \uparrow \text { HSP72 } \\
\text { provides cardioprotection by ischemia/reperfusion and } \\
\uparrow \text { post-ischemic recovery }\end{array}$ \\
\hline Osaki et al. ${ }^{[44]}$ & $\begin{array}{l}\text { To examine the involvement of protein kinase A and } \\
\text { protein kinase } C \text { in pressure-induced HSP70 expression }\end{array}$ & $\begin{array}{l}\text { Elevation of aortic pressure } \uparrow \text { HSP70 / } \uparrow \text { HSP70 are } \\
\text { regulated both by PKA and PKC-dependent systems }\end{array}$ \\
\hline Qian et al. ${ }^{[20]}$ & $\begin{array}{l}\text { To investigate the ischemic preconditioning } \\
\text { cardioprotection and to correlate with HSP70 expression }\end{array}$ & $\begin{array}{l}\text { Heat stress and preconditioning } \uparrow \text { HPS70 / heat stress } \\
\qquad \downarrow \text { infarct size }\end{array}$ \\
\hline Qiu et al. ${ }^{[73]}$ & $\begin{array}{c}\text { To determine the function of HSP22 in cardiac overload } \\
\text { pressure }\end{array}$ & $\begin{array}{l}\text { HSP22 deletion accelerates transition to HF in the } \\
\text { context of cardiac overload pressure }\end{array}$ \\
\hline Rahsepar et al. ${ }^{[72]}$ & $\begin{array}{c}\text { To analyze the levels of HSP27 in patients with valvular } \\
\text { heart disease }\end{array}$ & $\begin{array}{c}\text { 个 HSP27 in patients with valvular heart disease / } \\
\uparrow \text { HSP27 may be useful as a biomarker in the } \\
\text { assessment of HF }\end{array}$ \\
\hline Raju et al. ${ }^{[45]}$ & $\begin{array}{l}\text { To investigate the regulation of HSP32 in the right-sided } \\
\text { congestive heart failure model }\end{array}$ & Congestive heart failure $\uparrow \mathrm{HSP} 32$, but $\leftrightarrow \mathrm{HSP} 70$ \\
\hline Rinaldi et al. ${ }^{[8]}$ & $\begin{array}{l}\text { To observe the effects of age and exercise on the } \\
\text { antioxidant system and expression of HSP27 and HSP70 }\end{array}$ & $\begin{array}{c}\text { Physical exercise } \uparrow \text { HSP27 and } \uparrow \text { HSP70 / } \uparrow \text { HSP27 and } \\
\uparrow \text { HSP70 } \downarrow \text { the deleterious effect of age on the } \\
\text { antioxidant system of the heart }\end{array}$ \\
\hline $\begin{array}{l}\text { Rothenbacher et } \\
\text { al. }{ }^{[63]}\end{array}$ & $\begin{array}{l}\text { To investigate whether HSP60 is associated with heart } \\
\text { disease }\end{array}$ & $\begin{array}{l}\uparrow \text { HSP60 does not seem to be an independent risk } \\
\text { factor for coronary artery disease }\end{array}$ \\
\hline Satoh et al. ${ }^{[66]}$ & $\begin{array}{l}\text { To determine the relationship between blood HSP70 } \\
\text { and TLR4 after myocardial infarction }\end{array}$ & $\begin{array}{c}\uparrow \text { HSP70 in patients than controls / } \uparrow \text { HSP70 and } \\
\uparrow \text { cytokines mediated TLR4 receptor }\end{array}$ \\
\hline Schmitt et al. ${ }^{448]}$ & $\begin{array}{c}\text { To investigate the synthesis of HSP70 in the human } \\
\text { heart in vivo after CABG }\end{array}$ & $\begin{array}{l}\uparrow \text { HSP70 occurred after at least } 2 \text { hours of stress } \\
\text { induction by CABG }\end{array}$ \\
\hline Shinohara et al. ${ }^{[26]}$ & $\begin{array}{l}\text { To observe the effect of estrogen on the expression of } \\
\qquad \text { HSP72 after ischemic damage }\end{array}$ & $\begin{array}{c}\text { Estrogen } \downarrow \text { HSP72 induced by hyperthermia / } \uparrow \text { HSP72 } \\
\text { promotes ischemic protection }\end{array}$ \\
\hline Staib et al. ${ }^{[6]}$ & $\begin{array}{l}\text { To investigate the effect of heat stress and mechanical } \\
\text { overload on the HSP70 expression }\end{array}$ & $\begin{array}{c}\text { Hyperthermia, regardless of workload, resulted in } \\
\text { significant } \uparrow \mathrm{HSP} 70 \text { in the heart }\end{array}$ \\
\hline Tanonaka et al. ${ }^{[5]}$ & $\begin{array}{l}\text { To evaluate the HSP72 production level during CHF and } \\
\text { its relation to cardiac protection }\end{array}$ & $\begin{array}{c}\text { Hyperthermia } \uparrow \text { HSP72 in the } 2^{\text {nd }} \text { week, but not in } \\
\text { the } 8^{\text {th }} \text { week / } \uparrow \text { HSP72 was inversely correlated with } \\
\text { worsening of the cardiac parameters / Advanced HF } \\
\qquad \text { HSP72 }\end{array}$ \\
\hline Tanonaka et al. ${ }^{[43]}$ & $\begin{array}{l}\text { To verify the expression of HSP during the development } \\
\text { of HF }\end{array}$ & $\begin{array}{c}\uparrow \text { HSP27 and } \uparrow \text { HSP70 in the } 1^{\text {st }} \text { week, but not in the } 8^{\text {th }} \\
\text { week / There was } \uparrow \text { HSP60 only in the } 8^{\text {th }} \text { week }\end{array}$ \\
\hline Tanonaka et al. ${ }^{[39]}$ & $\begin{array}{l}\text { To examine the HSP72 expression in HF after acute } \\
\text { myocardial infarction }\end{array}$ & The development of HF $\downarrow$ HSP70 by hyperthermia \\
\hline
\end{tabular}




\begin{tabular}{|c|c|c|}
\hline Ugurlucan et al..10] & $\begin{array}{c}\text { To investigate the effect of diabetes mellitus and } \\
\text { glutamine administration on HSP70 expression in the } \\
\text { heart }\end{array}$ & $\begin{array}{c}\text { Diabetes } \uparrow \text { HSP70 in the myocardium / Parenteral } \\
\text { administration of glutamine } \uparrow \text { HSP70 }\end{array}$ \\
\hline Veres et al. ${ }^{[64]}$ & $\begin{array}{l}\text { To explore the relationship between familial risk for } \\
\text { heart disease and HSP60 }\end{array}$ & $\begin{array}{c}\uparrow \text { HSP60 in the group with high familial risk / Children } \\
\text { with } \uparrow \text { HSP60 showed higher values of odds ratio for } \\
\text { heart disease / } \uparrow \text { HSP60 can be considered a relative risk } \\
\text { factor for heart disease }\end{array}$ \\
\hline Vittorini et al. ${ }^{[14]}$ & $\begin{array}{l}\text { To assess the HSP70 gene expression during blood } \\
\text { cardioplegic arrest in children }\end{array}$ & $\begin{array}{l}\text { Blood cardioplegia } \uparrow \text { HSP70 and protection of the } \\
\text { ischemia/reperfusion injury }\end{array}$ \\
\hline Wang et al..[46] & $\begin{array}{l}\text { To investigate the regulation and transcription of HSP60 } \\
\text { and HSP72 in HF }\end{array}$ & $\begin{array}{c}\text { There were } \uparrow \text { HSP60 and } \uparrow \text { NF kB in HF / } \uparrow \text { HSP60 may } \\
\text { be mediated by } \uparrow \text { NFkB / } \leftrightarrow \text { HSP70 because } \leftrightarrow \text { HSF1 } \\
\text { in HF }\end{array}$ \\
\hline Wei et al. ${ }^{[15]}$ & $\begin{array}{l}\text { To observe protein changes in hearts with HF and to } \\
\text { identify potential biomarkers of this condition }\end{array}$ & $\begin{array}{l}\uparrow \text { HSP70 is the common feature of HF / } \uparrow \text { HSP70 may } \\
\text { be used as a biomarker for the presence of HF and may } \\
\text { hold diagnostic/prognostic potential in clinical practice }\end{array}$ \\
\hline Wu et al. ${ }^{[36]}$ & $\begin{array}{l}\text { To compare HSP expression in patients with and } \\
\text { without atrial fibrillation }\end{array}$ & $\downarrow$ HSP27 in patients with atrial fibrillation \\
\hline Xi et al. ${ }^{[37]}$ & $\begin{array}{l}\text { To investigue whether the whole-body heat stress } \\
\text { induces HSP70 expression and offers cardioprotection }\end{array}$ & $\begin{array}{l}\text { Whole-body heat stress } \uparrow \text { HSP70 / No differences in } \\
\text { HSP70 or control groups in infarct size after ischemia/ } \\
\text { reperfusion }\end{array}$ \\
\hline Yamanaka et al. ${ }^{[9]}$ & $\begin{array}{c}\text { To investigate the effect of treatment with } \\
\text { geranylgeranyl acetone (GGA) in the expression of } \\
\text { HSP72 }\end{array}$ & $\begin{array}{c}\text { Treatment with GGA } \uparrow \text { HSP72 and } \uparrow \text { HSF-1 / } \uparrow \text { the } \\
\text { recovery after ischemia/reperfusion / } \uparrow \text { HSP72 } \\
\text { promoted cardioprotection }\end{array}$ \\
\hline Yamashita et al. ${ }^{[18]}$ & $\begin{array}{l}\text { To compare the time course of tolerance to myocardial } \\
\text { injury with the time course of HSP70 induction }\end{array}$ & $\begin{array}{c}\downarrow \text { infarct size in } 48 \text { and } 72 \text { hours after heat stress } \\
/ \uparrow \text { HSP70 content correlates with time course of } \\
\text { cardioprotection }\end{array}$ \\
\hline Yan et al. ${ }^{[55]}$ & $\begin{array}{l}\text { To investigate the expression of HSP60 in the heart, liver, } \\
\text { and kidney of stressed broilers }\end{array}$ & $\begin{array}{c}\uparrow \text { HSP60 is specific and can be related to tissue damage } \\
\text { in response to thermal stress / In the heart } \uparrow \text { HSP60 } \\
\text { peaked at } 5 \mathrm{~h} \text { after stress }\end{array}$ \\
\hline Yu et al. ${ }^{[54]}$ & $\begin{array}{c}\text { To determine the HSP70 expression in cardiac and renal } \\
\text { tissues of transport-stressed pigs }\end{array}$ & Transport stress $\uparrow$ HSP70 in cardiac and renal tissues \\
\hline Yu et al. ${ }^{[50]}$ & $\begin{array}{l}\text { To examine the expression of HSP70 after several } \\
\text { periods of ischemia/reperfusion }\end{array}$ & $\begin{array}{c}\text { Permanent ischemia and ischemia/reperfusion } \uparrow \\
\text { HSP70 / } \uparrow \text { HSP70 from } 30 \text { min to } 24 \mathrm{~h} \text { after ischemia/ } \\
\text { reperfusion }\end{array}$ \\
\hline Zhang et al. ${ }^{[70]}$ & To observe the correlation of HSP60 and CHD & $\uparrow \mathrm{HSP} 60$ is related to the risk of CHD \\
\hline Zhang et al. ${ }^{[71]}$ & $\begin{array}{c}\text { To determine whether HSP60, hypertension and } \\
\text { diabetes have joint effects on CHD risk }\end{array}$ & $\begin{array}{l}\uparrow \mathrm{HSP} 60 \text { in the group with CHD than controls / } \uparrow \text { HSP60 } \\
\text { is positively correlated with the risk and severity of CHD }\end{array}$ \\
\hline Zhao et al. ${ }^{[32]}$ & $\begin{array}{l}\text { To examine the effects of probiotics-derived protein on } \\
\text { heart injury }\end{array}$ & $\begin{array}{c}\text { Probiotics-derived protein } \uparrow \text { HSP70 in heart cells and } \\
\qquad \text { damage of ischemia/reperfusion }\end{array}$ \\
\hline Zhong et al. ${ }^{[11]}$ & $\begin{array}{l}\text { To quantify the HSP70 levels hypoxia-induced and its } \\
\text { relation to cardioprotection }\end{array}$ & $\begin{array}{c}\text { Hypoxia } \uparrow \text { HSP70 and it provides protection against } \\
\text { ischemia/reperfusion / } \uparrow \text { HSP70 can stay up to two } \\
\text { weeks after hypoxia }\end{array}$ \\
\hline Zhu and Wang ${ }^{[29]}$ & $\begin{array}{l}\text { To explore whether overexpression of HSP2O in } \\
\text { cardiomyocytes protects against injury }\end{array}$ & $\uparrow$ HSP20 $\downarrow$ the necrotic and $\downarrow$ apoptotic cardiomyocytes \\
\hline
\end{tabular}

$\uparrow=$ increase; $\downarrow=$ decrease; $\leftrightarrow=$ no changes; CABG=coronary artery bypass grafting; CHD=coronary heart disease; CHF=chronic heart failure; $\mathrm{CK}=$ creatine kinase; $\mathrm{HF}=$ heart failure; $\mathrm{ICH}=$ intracerebral hemorrhage 


\section{Authors' roles \& responsibilities}

VASJ Substantial contributions to the conception or design of the work; or the acquisition, analysis, or interpretation of data for the work; drafting the work or revising it critically for important intellectual content; final approval of the version to be published

PCBL Substantial contributions to the conception or design of the work; or the acquisition, analysis, or interpretation of data for the work; drafting the work or revising it critically for important intellectual content; final approval of the version to be published

MAC Substantial contributions to the conception or design of the work; or the acquisition, analysis, or interpretation of data for the work; drafting the work or revising it critically for important intellectual content; final approval of the version to be published

CSM Substantial contributions to the conception or design of the work; or the acquisition, analysis, or interpretation of data for the work; drafting the work or revising it critically for important intellectual content; final approval of the version to be published

Substantial contributions to the conception or design of the work; or the acquisition, analysis, or interpretation of data for the work; drafting the work or revising it critically for important intellectual content; final approval of the version to be published

PNM Substantial contributions to the conception or design of the work; or the acquisition, analysis, or interpretation of data for the work; drafting the work or revising it critically for important intellectual content; final approval of the version to be published

\section{REFERENCES}

1. Kampinga HH, Hageman J, Vos MJ, Kubota H, Tanquay RM, Bruford $E A$, et al. Guidelines for the nomenclature of the human heat shock proteins. Cell Stress Chaperones. 2009;14(1):105-11.

2. Jolly C, Morimoto RI. Role of the heat shock response and molecular chaperones in oncogenesis and cell death. J Natl Cancer Inst. 2000;92(19):1564-72.

3. Jiang, BH, Jiang G, Zheng JZ, Lu Z, Hunter T, Vogt PK. Phosphatidylinositol 3-kinase signaling controls levels of hypoxia-inducible factor 1. Cell Growth Differ. 2001;12(7):363-9.

4. Beere HM. Death versus survival: functional interaction between the apoptotic and stress-inducible heat shock protein pathways. J Clin Invest. 2005;115(10):2633-9.

5. Tanonaka K, Furuhama Kl, Yoshida H, Kakuta K, Miyamoto Y, Toga W, et al. Protective effect of heat shock protein 72 on contractile function of perfused failing heart. Am J Physiol Heart Circ Physiol. 2001;281 (1):H215-22.

6. Staib JL, Quindry JC, French JP, Criswell DS, Powers SK. Increased temperature, not cardiac load, activates heat shock transcription factor 1 and heat shock protein 72 expression in the heart. Am J Physiol Regul Integr Comp Physiol. 2007;292(1):R432-9.

7. Marunouchi T, Murata M, Takagi N, Tanonaka K. Possible involvement of phosphorylated heat-shock factor-1 in changes in heat shock protein 72 induction in the failing rat heart following myocardial infarction. Biol Pharm Bull. 2013;36(8):1332-40

8. Rinaldi B, Corbi G, Boccuti S, FilippelliW, Rengo G, Leosco D, et al. Exercise training affects age-induced changes in SOD and heat shock protein expression in rat heart. Exp Gerontol. 2006;41(8):764-70.
9. Yamanaka K, Takahashi N, Ooie T, Kaneda K, Yoshimatsu H, Saikawa T. Role of protein kinase $\mathrm{C}$ in geranylgeranylacetone-induced expression of heat-shock protein 72 and cardioprotection in the rat heart. J Mol Cell Cardiol. 2003;35(7):785-94.

10. Ugurlucan M, Erer D, Karatepe O, Ziyade S, Haholu A, Gungor Ugurlucan $F$, et al. Glutamine enhances the heat shock protein 70 expression as a cardioprotective mechanism in left heart tissues in the presence of diabetes mellitus. Expert Opin Ther Targets. 2010;14(11):1143-56.

11. Zhong N, Zhang Y, Fang QZ, Zhou ZN. Intermittent hypoxia exposureinduced heat-shock protein 70 expression increases resistance of rat heart to ischemic injury. Acta Pharmacol Sin. 200;21(5):467-72.

12. Okubo S, Wildner O, Shah MR, Chelliah JC, Hess ML, Kukreja RC. Gene transfer of heat-shock protein 70 reduces infarct size in vivo after ischemia/reperfusion in the rabbit heart. Circulation. 2001;103(6):877-81.

13. Kwon JH, Kim JB, Lee KH, Kang SM, Chung N, Jang Y, et al. Protective effect of heat shock protein 27 using protein transduction domainmediated delivery on ischemia/reperfusion heart injury. Biochem Biophys Res Commun. 2007;363(2):399-404

14. Vittorini S, Storti S, Andreani G, Giusti L, Murzi B, Furfori P, et al. Heat shock protein 70-1 gene expression in pediatric heart surgery using blood cardioplegia. Clin Chem Lab Med. 2007;45(2):244-8.

15. Wei YJ, Huang YX, Shen Y, Cui CJ, Zhang XL, Zhang H, et al. Proteomic analysis reveals significant elevation of heat shock protein 70 in patients with chronic heart failure due to arrhythmogenic right ventricular cardiomyopathy. Mol Cell Biochem. 2009;332(1-2):103-11.

16. Bonanad C, Núñez J, Sanchis J, Bodi V, Chaustre F, Chillet M, et al. Serum heat shock protein 60 in acute heart failure: a new biomarker? Congest Heart Fail. 2013;19(1):6-10.

17. Li Z, Song Y, Xing R, Yu H, Zhang Y, Li Z, et al. Heat shock protein 70 acts as a potential biomarker for early diagnosis of heart failure. PLOS One. 2013;8(7):e67964.

18. Yamashita N, Hoshida S, Nishida M, Igarashi J, Aoki K, Hori M, et al. Time course of tolerance to ischemia-reperfusion injury and induction of heat shock protein 72 by heat stress in the rat heart. J Mol Cell Cardiol. 1997;29(7):1815-21.

19. Kukreja RC, Qian YZ, Okubo S, Flaherty EE. Role of protein kinase C and $72 \mathrm{kDa}$ heat shock protein in ischemic tolerance following heat stress in the rat heart. Mol Cell Biochem. 1999;195(1-2):123-31.

20. Qian YZ, Bernardo NL, Nayeem MA, Chelliah J, Kukreja RC. Induction of 72-kDa heat shock protein does not produce second window of ischemic preconditioning in rat heart. Am J Physiol. 1999;276(1 Pt 2):H224-34.

21. Meldrum DR, Meng X, Shames BD, Pomerantz B, Donnahoo KK, Banerjee $A$, et al. Liposomal delivery of heat-shock protein 72 into the heart prevents endotoxin-induced myocardial contractile dysfunction. Surgery. 1999;126(2):135-41.

22. Nomura F, Aoki M, Forbess JM, Mayer JE Jr. Myocardial self-preservative effect of heat shock protein 70 on an immature lamb heart. Ann Thorac Surg. 1999;68(5):1736-41.

23. Kim SO, Baines CP, Critz SD, Pelech SL, Katz S, Downey JM, et al. Ischemia induced activation of heat shock protein 27 kinases and casein kinase 2 in the preconditioned rabbit heart. Biochem Cell Biol. 1999;77(6):559-67.

24. Ooie T, Takahashi N, Saikawa T, Nawata T, Arikawa M, Yamanaka K, et al. Single oral dose of geranylgeranylacetone induces heat-shock protein 72 and renders protection against ischemia/reperfusion injury in rat heart. Circulation. 2001;104(15):1837-43.

25. Efthymiou CA, Mocanu MM, Belleroche J, Wells DJ, Latchmann DS, Yellon DM. Heat shock protein 27 protects the heart against myocardial infarction. Basic Res Cardiol. 2004;99(6):392-4.

26. Shinohara T, Takahashi N, Ooie T, Ichinose M, Hara M, Yonemochi H, et al. Estrogen inhibits hyperthermia-induced expression of heat-shock protein 72 and cardioprotection against ischemia/reperfusion injury in female rat heart. J Mol Cell Cardiol. 2004;37(5):1053-61.

27. Chen H, Wu XJ, Lu XY, Zhu L, Wang LP, Yang HT, et al. Phosphorylated heat 
shock protein 27 is involved in enhanced heart tolerance to ischemia in short-term type 1 diabetic rats. Acta Pharmacol Sin. 2005;26(7):806-12.

28. Gauthaman K, Banerjee SK, Dinda AK, Ghosh CC, Maulik SK. Terminalia arjuna (Roxb.) protects rabbit heart against ischemic-reperfusion injury: role of antioxidant enzymes and heat shock protein. J Ethnopharmacol. 2005;96(3):403-9.

29. Zhu YH, Wang X. Overexpression of heat-shock protein 20 in rat heart myogenic cells confers protection against simulated ischemia/ reperfusion injury. Acta Pharmacol Sin. 2005;26(9):1076-80.

30. Kohno H, Takahashi N, Shinohara T, Ooie T, Yufu K, Nakagawa M, et al. Receptor-mediated suppression of cardiac heat-shock protein 72 expression by testosterone in male rat heart. Endocrinology. 2007;148(7):3148-55.

31. Krishnamurthy K, Kanagasabai R, Druhan LJ, llangovan G. Heat shock protein 25-enriched plasma transfusion preconditions the heart against doxorubicin-induced dilated cardiomyopathy in mice. J Pharmacol Exp Ther. 2012;341(3):829-39.

32. Zhao B, Sun G, Feng G, Duan W, Zhu X, Chen S, et al. Carboxy terminus of heat shock protein (HSP) 70-interacting protein (CHIP) inhibits HSP70 in the heart. J Physiol Biochem. 2012;68(4):485-91.

33. Jiang B, Zhang B, Liang P, Chen G, Zhou B, Lv C, et al. Nucleolin protects the heart from ischaemia-reperfusion injury by up-regulating heat shock protein 32. Cardiovasc Res. 2013;99(1):92-101.

34. Li Q, Shi M, Li B. Anandamide enhances expression of heat shock protein 72 to protect against ischemia-reperfusion injury in rat heart. J Physiol Sci. 2013;63(1):47-53.

35. McGinley LM, McMahon J, Stocca A, Duffy A, Flynn A, O'Toole D, et al. Mesenchymal stem cell survival in the infarcted heart is enhanced by lentivirus vector-mediated heat shock protein 27 expression. Hum Gene Ther. 2013;24(10):840-51.

36. Wu W, Lu Z, Li Y, Chen Z, Jiang H, Li Y. Decreased Cardiac Expression of Heat Shock Protein 27 is Associated with Atrial Fibrillation in Patients with Rheumatic Heart Disease. Acta Cardiol Sin. 2015;31(1):1-7.

37. Xi L, Chelliah J, Nayeem MA, Levasseur JE, Hess ML, Kukreja RC. Whole body heat shock fails to protect mouse heart against ischemia/ reperfusion injury: role of $72 \mathrm{kDa}$ heat shock protein and antioxidant enzymes. J Mol Cell Cardiol. 1998;30(11):2213-27.

38. Moalic JM, Bauters C, Himbert D, Bercovici J, Mouas C, Guicheney P, et al. Phenylephrine, vasopressin and angiotensin II as determinants of proto-oncogene and heat-shock protein gene expression in adult rat heart and aorta. J Hypertens. 1989;7(3):195-201.

39. Tanonaka K, Toga W, Takahashi M, Yoshida H, Oikawa R, Takeo S. Induction of heat shock protein 72 in the failing heart is attenuated after an exposure to heat shock. Mol Cell Biochem. 2004;259(1-2):211-5.

40. Kukreja RC, Kontos MC, Loesser KE, Batra SK, Qian YZ, Gbur CJ Jr, et al. Oxidant stress increases heat shock protein 70 mRNA in isolated perfused rat heart. Am J Physiol. 1994;267(6 Pt 2):H2213-9.

41. Ferrari R, Bongrazio M, Cargnoni A, Comini L, Pasini E, Gaia G, et al. Heat shock protein changes in hibernation: a similarity with heart failure? J Mol Cell Cardiol. 1996;28(12):2383-95.

42. Comini L, Gaia G, Curello S, Ceconi C, Pasini E, Benigno M, et al. Right heart failure chronically stimulates heat shock protein 72 in heart and liver but not in other tissues. Cardiovasc Res. 1996;31 (6):882-90.

43. Tanonaka K, Toga W, Yoshida H, Takeo S. Myocardial heat shock protein changes in the failing heart following coronary artery ligation. Heart Lung Circ. 2003;12(1):60-5.

44. Osaki J, Haneda T, Kashiwagi Y, Oi S, Fukuzawa J, Sakai H, et al. Pressureinduced expression of heat shock protein 70 mRNA in adult rat heart is coupled both to protein kinase A-dependent and protein kinase C-dependent systems. J Hypertens. 1998;16(8):1193-200.

45. Raju VS, Imai N, Liang CS. Chamber-specific regulation of heme oxygenase-1 (heat shock protein 32) in right-sided congestive heart failure. J Mol Cell Cardiol. 1999;31(8):1581-9.

46. Wang Y, Chen L, Hagiwara N, Knowlton AA. Regulation of heat shock protein 60 and 72 expression in the failing heart. J Mol Cell Cardiol. 2010;48(2):360-6.

47. Knowlton AA, Sun L. Heat-shock factor-1, steroid hormones, and regulation of heat-shock protein expression in the heart. Am J Physiol Heart Circ Physiol. 2001;280(1):H455-64.

48. Schmitt JP, Schunkert H, Birnbaum DE, Aebert H. Kinetics of heat shock protein 70 synthesis in the human heart after cold cardioplegic arrest. Eur J Cardiothorac Surg. 2002;22(3):415-20.

49. Dybdahl B, Wahba A, Lien E, Flo TH, Waage A, Qureshi N, et al. Inflammatory response after open heart surgery: release of heatshock protein 70 and signaling through toll-like receptor-4. Circulation. 2002;105(6):685-90.

50. Yu H, Yokoyama M, Asano G. Time course of expression and localization of heat shock protein 72 in the ischemic and reperfused rat heart. Jpn Circ J. 1999;63(4):278-87.

51. Gray CC, Amrani M, Smolenski RT, Nakamura K, Yacoub MH. Cold cardioplegic arrest enhances heat shock protein 70 in the heat-shocked rat heart. J Thorac Cardiovasc Surg. 2001;121(6):1130-6.

52. Katayose D, Isoyama S, Fujita $H$, Shibahara S. Separate regulation of heme oxygenase and heat shock protein 70 mRNA expression in the rat heart by hemodynamic stress. Biochem Biophys Res Commun. 1993;191(2):587-94.

53. Knowlton AA, Eberli FR, Brecher P, Romo GM, Owen A, Apstein CS. A single myocardial stretch or decreased systolic fiber shortening stimulates the expression of heat shock protein 70 in the isolated, erythrocyte-perfused rabbit heart. J Clin Invest. 1991;88(6):2018-25.

54. Yu H, Bao ED, Zhao RQ, Lv QX. Effect of transportation stress on heat shock protein 70 concentration and mRNA expression in heart and kidney tissues and serum enzyme activities and hormone concentrations of pigs. Am J Vet Res. 2007;68(11):1145-50.

55. Yan J, Bao E, Yu J. Heat shock protein 60 expression in heart, liver and kidney of broilers exposed to high temperature. Res Vet Sci. 2009;86(3):533-8.

56. Hoppichler F, Lechleitner M, Traweger C, Schett G, Dzien A, Sturm $W$, et al. Changes of serum antibodies to heat-shock protein 65 in coronary heart disease and acute myocardial infarction. Atherosclerosis. 1996;126(2):333-8.

57. Dohke T, Wada A, Isono T, Fujii M, Yamamoto T, Tsutamoto T, et al. Proteomic analysis reveals significant alternations of cardiac small heat shock protein expression in congestive heart failure. J Card Fail. 2006;12(1):77-84.

58. Hu H, Wang L, Okauchi M, Keep RF, Xi G, Hua Y. Deferoxamine affects heat shock protein expression in heart after intracerebral hemorrhage in aged rats. Acta Neurochir Suppl. 2011;111:197-200.

59. Boluyt MO, Brevick JL, Rogers DS, Randall MJ, Scalia AF, Li ZB. Changes in the rat heart proteome induced by exercise training: Increased abundance of heat shock protein hsp20. Proteomics. 2006;6(10):3154-69.

60. Almela P, Martínez-Laorden E, Atucha NM, Milanés MV, Laorden ML. Naloxone-precipitated morphine withdrawal evokes phosphorylation of heat shock protein 27 in rat heart through extracellular signal-regulated kinase. J Mol Cell Cardiol. 2011;51(1):129-39.

61. Latif N, Yacoub MH, Dunn MJ. Association of pretransplant anti-heart antibodies against human heat shock protein 60 with clinical course following cardiac transplantation. Transplant Proc. 1997;29(1-2):1039-40.

62. Baba HA, Schmid KW, Schmid C, Blasius S, Heinecke A, Kerber $\mathrm{S}$, et al. Possible relationship between heat shock protein 70 , cardiac hemodynamics, and survival in the early period after heart transplantation. Transplantation. 1998;65(6):799-804.

63. Rothenbacher D, Hoffmeister A, Bode G, Miller M, Koenig W, Brenner $\mathrm{H}$. Helicobacter pylori heat shock protein 60 and risk of coronary heart disease: a case control study with focus on markers of systemic inflammation and lipids. Atherosclerosis. 2001;156(1):193-9.

64. Veres A, Szamosi T, Ablonczy M, Szamosi Jr T, Singh M, Karádi I, et al. Complement activating antibodies against the human $60 \mathrm{kDa}$ heat 
shock protein as a new independent family risk factor of coronary heart disease. Eur J Clin Invest. 2002;32(6):405-10.

65. Genth-Zotz S, Bolger AP, Kalra PR, von Haehling S, Doehner W, Coats $\mathrm{AJ}$, et al. Heat shock protein 70 in patients with chronic heart failure: relation to disease severity and survival. Int J Cardiol. 2004;96(3):397-401.

66. Satoh M, Shimoda Y, Akatsu T, Ishikawa Y, Minami Y, Nakamura M. Elevated circulating levels of heat shock protein 70 are related to systemic inflammatory reaction through monocyte Toll signal in patients with heart failure after acute myocardial infarction. Eur J Heart Fail. 2006;8(8):810-5.

67. Gombos T, Förhécz Z, Pozsonyi Z, Jánoskuti L, Prohászka Z. Interaction of serum 70-kDa heat shock protein levels and HspA1B (+1267) gene polymorphism with disease severity in patients with chronic heart failure. Cell Stress Chaperones. 2008;13(2):199-206.

68. Jafarzadeh A, Esmaeeli-Nadimi A, Shariati M. High sensitivity C-reactive protein and immunoglobulin $\mathrm{G}$ against Chlamydia pneumoniae and chlamydial heat shock protein-60 in ischemic heart disease. Iran J Immunol. 2008;5(1):51-6.
69. Niizeki T, Takeishi Y, Watanabe T, Nitobe J, Miyashita T, Miyamoto T, et al. Relation of serum heat shock protein 60 level to severity and prognosis in chronic heart failure secondary to ischemic or idiopathic dilated cardiomyopathy. Am J Cardiol. 2008;102(5):606-10.

70. Zhang X, He M, Cheng L, Chen Y, Zhou L, Zeng H, et al. Elevated heat shock protein 60 levels are associated with higher risk of coronary heart disease in Chinese. Circulation. 2008;118(25):2687-93.

71. Zhang X, He MA, Cheng L, Zhou L, Zeng H, Wang J, et al. Joint effects of antibody to heat shock protein 60, hypertension, and diabetes on risk of coronary heart disease in Chinese. Clin Chem. 2008;54(6):1046-52.

72. Rahsepar AA, Mirzaee A, Moodi F, Moohebati M, Tavallaie S, Eshraghi A, et al. Anti-heat shock protein 27 titers and oxidative stress levels are elevated in patients with valvular heart disease. Angiology. 2012;63(8):609-16.

73. Qiu H, Lizano P, Laure L, Sui X, Rashed E, Park JY, et al. H11 kinase/heat shock protein 22 deletion impairs both nuclear and mitochondrial functions of STAT3 and accelerates the transition into heart failure on cardiac overload. Circulation. 2011;124(4):406-15. 